\title{
Spatial distribution of soybean plants infested with whitefly Bemisia tabaci (Gennadius, 1889) (Hemiptera: Aleyrodidae)*
}

\author{
Distribuição espacial de plantas infestadas por mosca-branca \\ Bemisia tabaci (Gennadius, 1889) (Hemiptera: Aleyrodidae) em soja
Renato Suekane ${ }^{1 * *}$, Paulo Eduardo Degrande', Elmo Pontes de Melo', Thiago Moreira Azambuja', Carlos Tutida Menegati ${ }^{1}$

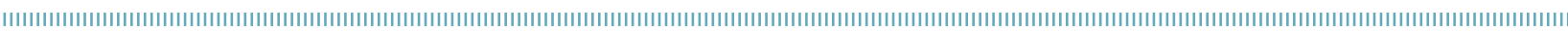

\begin{abstract}
The determination of the spatial distribution of a pest is the first step in the establishment of a sampling plan, as sampling methods are contingent upon the type of spatial distribution of the specific pest studied, varying according to the number and size of samples in the area. This work aimed to study the spatial distribution of soybean plants infested with Bemisia tabaci, under field conditions, through the determination of the aggregation indices and the chi-square test of fitness to the main types of theoretical frequency distributions. The average percentage of whitefly (B. tabaci) infestation increasing after the V1 stage, reaching the maximum infestation of $60.3 \%$ in the R1 stage. At the R2 stage, the percentage of infestation ranged from 20 to $40 \%$. According to the models of theoretical distributions studied, the Poisson distribution best defines the distribution of the whitefly.
\end{abstract}

KEYWORDS: spatial arrangement; biotype B; dispersion index; Glycine max.
RESUMO: A determinação do arranjo espacial da praga torna-se o primeiro passo para o estabelecimento de um plano de amostragem, pois, conforme o tipo de distribuição espacial da praga específica estudada, será necessário utilizar diferentes métodos de amostragem, variando o número e o tamanho da amostra na área. O presente trabalho objetivou estudar a distribuição espacial das plantas infestadas por Bemisia tabaci em condiçóes de campo, na cultura da soja, por meio da determinaçáo dos índices de agregação e dos testes de qui-quadrado de aderência para os principais tipos de distribuiçóes teóricas de frequência. Os resultados mostraram que a porcentagem média de infestação da mosca-branca (B. tabaci) foi aumentando a partir do estádio V1, atingindo a máxima infestação de $60,3 \%$ no estádio R1. A partir do estádio R2, a porcentagem de infestação variou entre $20 \%$ e 40\%. Os modelos de distribuiçôes teóricas estudados indicam que o modelo poisson é o que melhor define a distribuição da mosca-branca.

PALAVRAS-CHAVE: arranjo espacial; biótipo B; índice de dispersão; Glycine max.

'Universidade Federal da Grande Dourados - Dourados (MS), Brazil

*This study is part of the master's thesis of the first author.

**Corresponding author: rsuekane@hotmail.com

Received on: 08/29/2016. Accepted on: 04/05/2018

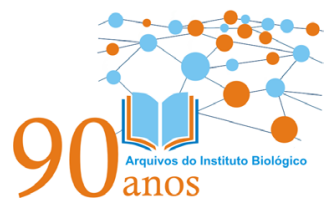




\section{INTRODUCTION}

The whitefly Bemisia tabaci (Gennadius, 1889) (Hemiptera: Aleyrodidae) causes economic damage to several crops, including soybean Glycine $\max$ (L.) Merrill, by extracting a large amount of sap from the phloem and negatively affecting plant growth and development. This insect also excretes a large amount of molasses (honeydew), which is rich in sugar and serves as a substrate for the development of the sooty mold-causing fungus Capnodium spp. (Capnodiaceae), thereby decreasing photosynthesis and in some cases leading to plant death (LOPEZ et al., 2008). This species has the ability to transmit viruses, and in soybeans, $B$. tabaci is a transmitter of the stem-necrosis virus (Carlavirus), which can lead to death of the host. A range of resistance responses to this pest has been observed among soybean genotypes (DEGRANDE; VIVAN, 2010).

B. tabaci has been recognized as a pest for several crops for many years, but its populations used to be small to the point of not causing economic damages. However, from the year 2001 on, the first population outbreaks of this pest in potato crops were reported (LOURENÇÃO et al., 2003). Outbreaks have also been reported in the Central-West region of Brazil, where this pest has been economically damaging soybean crops (DEGRANDE; VIVAN, 2010).

In order to carry out the sustainable management of $B$. tabaci, reliable sampling plans that allow estimating the population density of this pest have to be constructed, as well as classifying its damages, and from this data, then make the appropriate decision (FARIAS et al. 2001). Thus, the determination of the spatial arrangement of the pest becomes the first step in the establishment of a sampling plan (FERNANDES et al., 2003), because the sampling method deployed will be contingent on the type of spatial distribution of the specific pest studied, varying according to number and size of samples in the area (MELO et al., 2006).

In order to determine the spatial arrangement pattern of a given species, it is necessary to have counting data of individuals in the ecosystem under study. Therefore, it is key that the ecosystem in question allows for sampling. These sampling, according to YOUNG; YOUNG (1998), can be used to infer the distribution of the sampled population or the characteristics of its distribution. For the description of the distribution patterns of a population, aggregation indices and frequency distributions are used.

This work aimed to study the spatial distribution of plants infested by Bemisia tabaci, in a soybean crop, by determining aggregation indices and the chi-square test of fitness to the main types of theoretical frequency distributions.

\section{MATERIALS AND METHODS}

The study was conducted at the experimental station of Centro Universitário da Grande Dourados (Unigran), located at the municipality of Dourados, state of Mato Grosso do Sul (MS), Brazil, latitude $22^{\circ} 14^{\circ} \mathrm{S}$, longitude $54^{\circ} 49^{\circ} \mathrm{W}$, and altitude of $458 \mathrm{~m}$ and a Cfa climate (humid mesothermic climate without drought).

Seeding was performed on December $5^{\text {th }}, 2009$. The cultivar used for the study was Don Mario 7.0i (BMX Magna ${ }^{\circledR}$ $\mathrm{RR})$. Line spacing was 0.45 meters with 14 plants per meter. There was no insecticide seed treatment. Control of weeds and diseases were performed with specific herbicides and fungicides recommended for the crop that do not affect the whitefly population. The control of defoliating pests was carried out with biological insecticide Dipe ${ }^{\circledR}$, with Bacillus thuringiensis as active ingredient, innocuous to the whitefly.

In the experiment, the data of 11,000 plants were counted in total from the evaluations. Each experimental unit consisted of 22 rows by ten meters in length $\left(99 \mathrm{~m}^{2}\right) ; 100$ plots were evaluated at each time point, occupying an area of 1 hectare. In each plot, ten plants were evaluated in a total of 1,000 plants per time point. The sampling was carried out in the dates of $12 / 15 / 2009,12 / 21 / 2009,12 / 28 / 2009$, $01 / 05 / 2009,01 / 12 / 2009,01 / 18 / 2009,01 / 29 / 2009$, $02 / 01 / 2009,02 / 08 / 2009,02 / 18 / 2009$ and 02/23/2009, totaling 11 evaluations.

The sampling was conducted as described by MELO et al. (2006), evaluating presence-absence of infested plants. A plant was considered infested when a nymph and/or an adult of the pest were found. The presence-absence sampling type is similar to that adopted by ELLSWORTH; DIEHL (1997). This type of evaluation has advantages, including smaller variation among the samplers and, at the same time, presents greater efficiency and precision for decision-making. In the presence-absence observations of plants infested by the pest, the direct counting technique reported by RODRIGUES et al. (2010) was employed.

The data obtained in each of the samples were used for the mathematical description of the spatial dispersion of the insect population. The mean, variance and aggregation indices were determined. The following theoretical distributions of frequencies were used as models for population samples: Poisson distribution, negative binomial distribution and positive binomial distribution. Then, the theoretical frequency distribution models' fitness to the data obtained in the field were compared using the chi-squared statistic.

The aggregation indices used to verify the degree of aggregation of the whitefly were: variance/mean ratio, morisite index and $\mathrm{K}$ index as reported by PEREIRA et al. (2004) and the theoretical frequency distributions used to evaluate the spatial distribution of Bemisia tabaci were: Poisson distribution, positive binomial distribution and negative 
binomial distribution, according to the methodology used by MELO et al. (2006).

\section{RESULTS AND DISCUSSION}

\section{Pest Population Dynamics}

The mean percentage of whitefly infestation (B. tabaci) increased after the V1 stage, reaching the maximum infestation of $60.3 \%$ in the R1 stage (January $11^{\text {th }}, 2010$ ). At the R2 stage, the percentage of infestation ranged from 20 to $40 \%$, making a total of 447 to 603 nymphs or adults of whitefly between the R1 and R2 stages of the total soybean plants per evaluation (Fig. 1). This whitefly population peak in January was also reported by RODRIGUES et al. (1997), in which

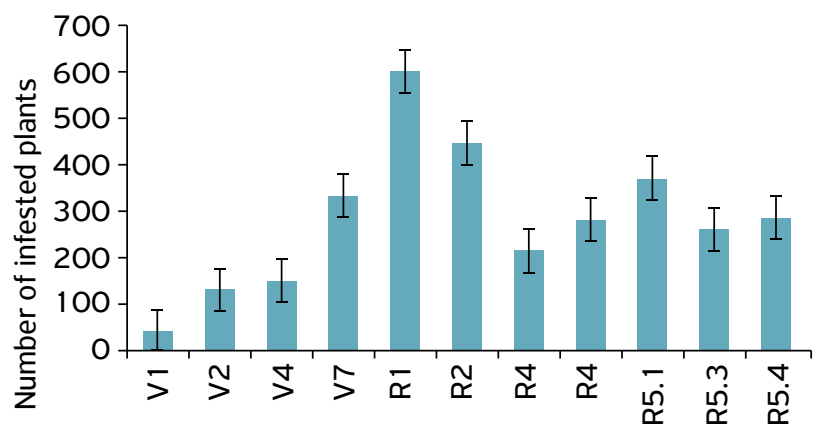

Phonological state

Figure 1. Occurrence and standard error of the mean number of plants infested by the whitefly in the experimental area in the phonological stages of the soybean cultivar Don Mario ${ }^{\circledR}$ 7.0i. Dourados, MS, 2010. the author cites the favorable conditions for the development of the pest registered in the month of January.

These developments of population peaks were also favored by the environmental conditions, with the average temperature varying between $24.9^{\circ} \mathrm{C}$ and $25.9^{\circ} \mathrm{C}$ from December, 2009 to February, 2010. The average temperature in the field studied was favorable for the development of whitefly populations, because, according to ALBERGARIA et al. (2002), the temperature range of $25^{\circ} \mathrm{C}$ to $30^{\circ} \mathrm{C}$ is favorable for the survival rate of the pest, with an acceleration in the whitefly biological cycle of 70.9 days at a temperature of $15^{\circ} \mathrm{C}$ to 21.8 days at $30^{\circ} \mathrm{C}$.

\section{Dispersion indices}

Based on the samplings performed in the study, the variance/ mean ratio (I), Morisita index $\left(\mathrm{I}_{\delta}\right)$ and $\mathrm{K}$ index values (Table 1) were calculated. In the experiment, it was observed that the values obtained for index I did not show significant differences, indicating a random distribution of the pest. The $\mathrm{I}_{\delta}$ index was not statistically significant, also indicating a random distribution. It was observed, however, that index I and index $I \delta$ in the sixth, eighth, ninth, tenth and eleventh samplings, tended to uniformity, since the values of both indices are smaller than the unit. The values found for the $\mathrm{K}$ index showed an aggregate distribution in the first four evaluations. Between the fifth and seventh evaluations, there was a shift in the distribution pattern of plants infested by whitefly (B.tabaci), since the values tended to be randomized, while in the sixth evaluation, they indicated a uniform distribution, again indicating the same uniform arrangement from the eighth evaluation.

The samplings indicate that, for index I, a random distribution was shown, since its values were not significantly

Table 1. Dispersion indices or aggregation, evaluation date, medium of infested plants, variance and spatial distribution indices used for infested plants by whitefly (B. tabaci) during the 11 evaluations. I (variance/mean ratio), $I_{\delta}$ (morisite index) and K (K index). Dourados, MS, 2010.

\begin{tabular}{|c|c|c|c|c|c|c|c|}
\hline Sampling & Date & Phonological State & Mean & Variance & I & $I_{\delta}$ & K \\
\hline 1 & 15/12/09 & V1 & 0.430 & 0.631 & $1.468^{\mathrm{ns}}$ & $2.104^{\mathrm{ns}}$ & $0.918^{\mathrm{AG}}$ \\
\hline 2 & 21/12/09 & V2 & 1.320 & 2.341 & $1.773^{\text {ns }}$ & $1.584^{\mathrm{ns}}$ & $1.706^{\mathrm{AG}}$ \\
\hline 3 & 28/12/09 & V4 & 1.510 & 2.171 & $1.438^{\mathrm{ns}}$ & $1.289^{\mathrm{ns}}$ & $3.446^{\mathrm{AG}}$ \\
\hline 4 & $05 / 01 / 10$ & V7 & 3.350 & 5.300 & $1.582^{\mathrm{ns}}$ & $1.172^{\mathrm{ns}}$ & $5.753^{\mathrm{AG}}$ \\
\hline 5 & $12 / 01 / 10$ & $\mathrm{R} 1$ & 6.030 & 6.716 & $1.113^{\mathrm{ns}}$ & $1.018^{\mathrm{ns}}$ & $52.980^{R D}$ \\
\hline 6 & $18 / 01 / 10$ & $\mathrm{R} 2$ & 4.470 & 2.494 & $0.558^{\text {ns }}$ & $0.902^{\text {ns }}$ & $-10.112^{\mathrm{UN}}$ \\
\hline 7 & 29/01/10 & R4 & 2.150 & 2.230 & $1.037^{\mathrm{ns}}$ & $1.017^{\mathrm{ns}}$ & $57.927^{\mathrm{RD}}$ \\
\hline 8 & $01 / 02 / 10$ & R4 & 2.830 & 2.162 & $0.764^{\text {ns }}$ & $0.917^{\mathrm{ns}}$ & $-12.002^{\mathrm{UN}}$ \\
\hline 9 & $08 / 02 / 10$ & R5. 1 & 3.720 & 3.072 & $0.825^{\text {ns }}$ & $0.953^{\text {ns }}$ & $-21.366^{\mathrm{UN}}$ \\
\hline 10 & $18 / 02 / 10$ & R5.3 & 2.620 & 1.672 & $0.638^{\text {ns }}$ & $0.863^{\text {ns }}$ & $-7.243^{\mathrm{UN}}$ \\
\hline 11 & $23 / 02 / 10$ & R5.4 & 3.880 & 2.470 & $0.637^{\text {ns }}$ & $0.907^{\text {ns }}$ & $-10.679^{\text {un }}$ \\
\hline
\end{tabular}

${ }^{\mathrm{n}}$ indicates non-significant $5 \%$ probability; ${ }^{\mathrm{AG}} \mathrm{Aggregate}$; ${ }^{\mathrm{N}}$ Uniform; ${ }^{\mathrm{RD}}$ Random 
different from on (01). When analyzing the $\mathrm{I}_{\delta}$ index, it was inferred that a sufficient number of infested plants was found in all samples to allow the determination of the index; the calculated values did not differ significantly from the unit thereby framing them in a random arrangement. Thus, it is observed that the values for both indices indicate a random distribution. However, from the eighth evaluation, there was a tendency for uniformity, since its values were smaller than one. For index K, the distribution was indicated to be aggregated in the initial infestations, and became uniform throughout the evaluations (Table 1). This was explained by BARBOSA; PERECIN (1982): in situations of high infestation, there is a tendency for uniform distribution and, according to MELO et al. (2006), this behavior may be related to the increase of intraspecific competition that causes individuals from the same population to move as far apart as possible from each other.

\section{Frequency Distributions}

The values of the chi-squares obtained for the plants infested with $B$. tabaci were included in the three theoretical frequency distribution models (Table 2). Significant values can be observed, indicating that the field counting data do fit the theoretical distribution models considered: four samplings fit the Poisson distribution $\left(1^{\text {st }}, 2^{\text {nd }}, 4^{\text {th }}, 8^{\text {th }}\right.$ and $\left.11^{\text {th }}\right)$, six fit positive binomial $\left(1^{\text {st }}, 2^{\text {nd }}, 3^{\text {rd }}, 4^{\text {th }}, 5^{\text {th }}\right.$ and $\left.6^{\text {th }}\right)$ and 8 fit negative binomial $\left(3^{\text {td }}, 5^{\text {th }}, 6^{\text {th }}, 7^{\text {th }}, 8^{\text {th }}, 9^{\text {th }}, 10^{\text {th }}\right.$ and $\left.11^{\text {th }}\right)$. In the context of ecological statistics, it can be accepted that the best fit is represented by the frequency distribution that presents the lowest value of the calculated $\chi^{2}$. In the present study, it was noted that the beginning of the infestation of soybean plants by whitefly occurs in aggregate form, going through a transition in the third evaluation to random, and to aggregated in the fourth evaluation, returning to be random from the fifth to the seventh evaluation. From the eighth evaluation, a shift occurred again, tending to a uniform distribution in the eighth evaluation, random in the ninth evaluation and remaining uniform in the last two evaluations. Several studies considering the presence-absence of pest insects point to this uniformity at a given moment of the infestation of the pests to the field (VILLACORTA; GUTIERREZ, 1989; FARIAS et al., 2001).

According to the frequency distributions data, the behavior of the plants infested by the species B. tabaci occurred at first in an aggregated form, characterizing the beginning of the infestations. After the establishment of the whitefly in the soybean field, the infested plants were characterized in a random arrangement and, finally, when a widespread infestation occurred in the soybean field, where the pest population the reached its maximum size, the uniform model best describes the arrangement of the infested plants. This pattern of spatial distribution of infested plants, in which the pest population goes through these three distinct stages, is common for insect pest populations that multiply in a short time. This same behavior was also observed by MELO et al. (2006) while studying the distribution of plants infested by Spodoptera frugiperda in maize. Due to the adjustment of the three theoretical frequency distributions used in this work to the counting data obtained in the sampled area, it is not possible, based only on the chi-square tests, to discard any theoretical dispersion pattern.

The aggregation of insects can occur when there is reproductive purpose, in response to meteorological changes such as

Table 2. Chi-square test $\left(\chi^{2}\right)$ for fitness of theoretical Poisson, positive binomial (bp) and negative binomial (bn) frequencies for plants infested by whitefly (B. tabaci) during the 11 evaluations. Dourados, MS, 2010

\begin{tabular}{cccccc} 
Sampling & Date & $\begin{array}{c}\text { Phonological } \\
\text { State }\end{array}$ & $\begin{array}{c}\text { Poisson } \\
\chi^{2}\end{array}$ & $\begin{array}{c}\text { bp } \\
\chi^{2}\end{array}$ & $\begin{array}{c}\text { bn } \\
\chi^{2}\end{array}$ \\
\hline 1 & $15 / 12 / 2009$ & $\mathrm{~V} 1$ & $38.748^{* *}$ & $4.914^{*}$ & $6.104^{\text {ns }}$ \\
\hline 2 & $21 / 12 / 2009$ & $\mathrm{~V} 2$ & $11.645^{* *}$ & $15.893^{* *}$ & $4.899^{\text {ns }}$ \\
\hline 3 & $28 / 12 / 2009$ & $\mathrm{~V} 4$ & $3.113^{\text {ns }}$ & $3.934^{*}$ & $16.519^{* *}$ \\
\hline 4 & $05 / 01 / 2010$ & $\mathrm{~V} 7$ & $40.980^{* *}$ & $107.610^{* *}$ & $15.084^{* *}$ \\
\hline 5 & $12 / 01 / 2010$ & $\mathrm{R} 1$ & $5.572^{\text {ns }}$ & $154.938^{* *}$ & $38.131^{* *}$ \\
\hline 6 & $18 / 01 / 2010$ & $\mathrm{R} 2$ & $5.519^{\text {ns }}$ & $5.037^{*}$ & $54.148^{* *}$ \\
\hline 7 & $29 / 01 / 2010$ & $\mathrm{R} 4$ & $1.108^{\text {ns }}$ & $3.687^{\text {ns }}$ & $30.997^{* *}$ \\
\hline 8 & $01 / 02 / 2010$ & $\mathrm{R} 4$ & $4.710^{\text {ns }}$ & $2.556^{\text {ns }}$ & $59.582^{* *}$ \\
\hline 9 & $08 / 02 / 2010$ & $R 5.1$ & $0.957^{\text {ns }}$ & $2.266^{\text {ns }}$ & $63.500^{* *}$ \\
\hline 10 & $18 / 02 / 2010$ & $R 5.3$ & $4.191^{\text {ns }}$ & $1.286^{\text {ns }}$ & $69.507^{* *}$ \\
\hline 11 & $23 / 02 / 2010$ & $R 5.4$ & $8.758^{*}$ & $3.840^{\text {ns }}$ & $82.803^{* *}$ \\
\hline
\end{tabular}

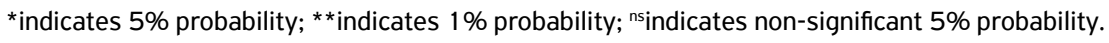


temperature, humidity, wind, and lightness, in case of social attractions and in situations where the unequivocal action of parasitoids and predators occurs (MESINA, 1986).

According to FERNANDES (2002), a population that characteristically presents aggregate type distribution, for example, can alternate this model to random or uniform due to the influence of biotic or abiotic factors. This shift has been observed in the population of Alabama argillacea.

When the spatial arrangement of the pest is random, any dimension of the sample unit is equally efficient for the estimation of population parameters, and this efficiency is defined in terms of the relative quantity of sample units needed to provide estimates of desirable accuracy (FERNANDES, 2003). However, the number of sample units to determine the special arrangement, according to this same author, is always suggested to be large samples, that is, over 50 units for the most complicated case in a population of the contagious type. For this study, double the suggested experimental units were used, that is, 100 units were evaluated in order to have accuracy in the obtained data.

At the moment when the calculated aggregation indices indicated the random distribution of the infested plants, there is a tendency of the pest to disperse and to arrange in a random way due to its capacity of dispersion, migratory activity and search for food. Similar behavior was mentioned in the works by MELO et al. (2006) and FARIAS et al. (2001).

Based on dispersion indices and theoretical frequency distribution models, the Poisson model best defines the distribution of the infested plants in the soybean crop, evidencing that the distribution of infested plants is random in the field. Thus, all individuals have the same probability of occupying any place in space, and the presence of an individual in one place does not affect the presence of another in a place near it (GREEN, 1966). This fact differs in relation to different crops, as in the case of beans, in which PEREIRA et al. (2004) describes the spatial distribution of whitefly as being regular or uniform. In the case of cotton, RODRIGUES et al. (2010) describes an aggregate arrangement of $B$. tabaci in both the Bt and conventional cultivars. Also, in cucumber crops, MOURA et al. (2003) defines the arrangement of the pest as an aggregate, showing that this pest, besides poly-phase (FONTES et al., 2010), is distributed in different arrangements.

From the information obtained in this study, we suggest the elaboration of a sequential sampling plan of infested plants for the soybean crop, since these plans are elaborated based on their arrangement (be it random, aggregate or uniform), varying mainly in the number of points to be sampled in the field, obtaining faster and more efficient information in the samples of the fields of soy production where the problem with this pest occurs.

\section{CONCLUSION}

The spatial distribution of soybean plants infected by whitefly (B. tabaci), according to the theoretical distribution models applied, indicates that the Poisson model best defines the distribution of this pest in the soybean fields, showing that the pest is distributed randomly in the field.

\section{ACKNOWLEDGMENTS}

The authors are would like to thank Capes (Coordination of Improvement of Higher Level Personnel) for the master's degree scholarship granted to the first author.

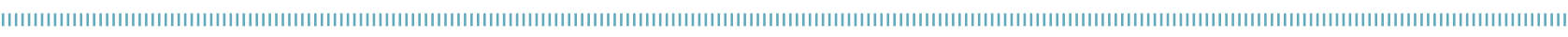

\section{REFERENCES}

ALBERGARIA, N.M.M.S; CIVIDANES, F.J. Exigências térmicas de Bemisiatabaci (Genn.) biótipo B (Hemiptera: Aleyrodidae). Neotropical Entomology, v.31, p.359-363, 2002.

BARBOSA, J.C.; PERECIN, D. Modelos probabilísticos para distribuição de lagartas de Spodopterafrugiperda (J.E. Smith, 1797), na cultura do milho. Científica, v.1, n.1, p.181-191, 1982.

BYRNE, D.N. Migration and dispersal by the sweet potato whitefly, Bemisiatabaci.Agriculture forMeteorology, v.97, n.1, p.309-316, 1999.

DEGRANDE, P.E.; VIVAN, L.M. Boletim de pesquisa de soja 2010. Fundação MT, v.1, n.1, p.152-215, 2010.
ELLSWORTH, P..; DIEHL, J. Whiteflies in Arizona: Evaluation of sampling plans. Cooperative Extension, v.1, n.1, p.2, 1997.

FARIAS, P.R.S.; BARBOSA, J.C.; BUSOLI, A.C. Amostragem sequencial (presença-ausência) para Spodoptera frugiperda (J.E. Smith) (Lepidoptera: Noctuidae) na cultura do milho. Neotropical Entomology, v.30, n.4, p.691-695, 2001.

FARIAS, P.R.S.; BARBOSA, J.C.; BUSOLI, A.C. Distribuição espacial da lagarta-do-cartucho, Spodoptera frugiperda (J.E.Smith) (Lepidoptera: Noctuidae), nacultura do milho. Neotropical Entomology, v.30, n.4, p.681-689, 2001. http://dx.doi. org/10.1590/S1519-566X2001000400025 
FERNANDES, M.G., BUSOLI, A.C., BARBOSA, J.C. Distribuição espacial de Spodoptera frugiperda (J.E. Smith, 1797) (Lepidoptera, Noctuidae) em algodoeiro. Revista Brasileira de Agrociência, v.8, n.3, p.203-21 1, 2002. http://dx.doi.org/10.12741/ebrasilis.v10i2.683

FERNANDES, O.D.; PARRA, J.R.P.; FERREIRA NETO, A.; PÍCOLI, R., BORGATTO, A.F.; DEMÉTRIO, G.B. Efeito do milho geneticamente modificado (MON810) sobre a lagarta-do-cartucho Spodoptera frugiperda (J.E. Smith, 1797) (Lepdoptera: Noctuidae). Revista Brasileira de Milho e Sorgo, v.2, n. 1, p.25-35, 2003. http://dx.doi. org/10.18512/1980-6477/rbms.v2n2p25-35

FONTES, F.V.H.M.; COLOMBO, C.A.; LOURENÇÃO, A.L. Caracterização molecular e divergência agenética de Bemisia tabaci(Genn.) (Hemiptera: Aleyrodidae) em diferentes culturas e locais de cultivo. Neotropical Entomology, v.39, n.2, p.221-226, 2010.

GREEN, R.H. Measurement of non-randomness in spatial distributions. Research Population Ecology, v. 8, n. 1, p. 1-7, 1966.

LOPEZ V.; VOS, J.; POLAR, P.; KRAUSS, U. Discovery learning about sustainable management of whitefly pests and whitefly-borne viruses. International Centre for Tropical Agriculture, v.1, n.1, p. 12-29, 2008.

LOURENÇÃO A.L.; SOUSA DIAS, J.A.; FUGI, C.Q. Mosca-branca: superpraga da agricultura mundial ameaça a bataticultura brasileira. Batata Show, v.6, n.1, p.7-8, 2003.

MELO, E.P.; FERNANDES, M.G.; DEGRANDE, P.E.; CESSA, R.M.A.; SALOMÃO, J.L.; NOGUEIRA, R.F. Distribuição espacial de plantas infestadas por Spodoptera frugiperda (J.E. Smith) (Lepdoptera: Noctuidae) na cultura do milho. Neotropical Entomology, v.35, n.5, p.689-697, 2006. http://dx.doi.org/10.1590/ S1519-566X2006000500018

MESINA, R.R.V. Disposição espacial de Panonychusulmi (Koch, 1836) (Acarina: Tetranychidae) e determinação do número de amostras na macieira. 1986. 88f. Dissertação (Mestrado em Entomologia) - Universidade Federal do Paraná, Curitiba, 1986.

MOURA, M.F.; PICANÇO, M.C.; SILVA, E.M.; GUEDES, R.N.C.; PEREIRA, J.L. Plano de amostragem do biótipo B de Bemisia tabaci na cultura do pepino. Pesquisa Agropecuária Brasileira, v.38, n.12, p.1357-1363, 2003.

NARANJO, S.; FLINT, H.M. Spatial distribution of adult Bemisia tabaci (Homoptera: Aleyrodidae) in cotton and development of fixed-precision sequential sampling plans for estimating population density. Environmental Entomology, v.24, n.2, p.261-270, 1995.

PEREIRA, M.F.A.; BOIÇA JR., A.L.; BARBOSA, J.C. Distribuição espacial de Bemisia tabaci (Genn) Biótipo B (Hemiptera: Aleyrodidae) em Feijoeiro (Phaseolus vulgaris L.). Neotropical Entomology, v.33, n.4, p.493-498, 2004. http://dx.doi. org/10.1590/S1519-566X2004000400015

RODRIGUES, T.R.; FERNANDES, M.G.; SANTOS, H.R. Distribuição espacial de Aphis gossypii (Glover) (Hemiptera, Aphididae) e Bemisia tabaci (Gennadius) biótipo B (Hemiptera, Aleyrodidae) em algodoeiro Bt e não-Bt. Revista Brasileira de Entomologia, v.54, n.1, p.136-143, 2010. http://dx.doi.org/10.1590/ S0085-56262010000100019

RODRIGUES, F.A; BORGES, A.C.F.; SANTOS, M.R.; FERNANDES, J.J.; FREITAS JUNIOR, A. Flutuação populacional da mosca-branca e a incidência de mosaico dourado em feijoeiro. Pesquisa Agropecuária Brasileira, v.32, n.10, p.1023-1027, 1997.

VILLACORTA, A.; GUTIERREZ, A.P. Presence-absence sampling decision rules for the damage cause by the coffee leaf miner (Leucoptera coffeella Guerin-Meneville, 1842). Pesquisa Agropecuária Brasileira, v.24, n.5, p.517-525, 1989.

YOUNG, L.J.; YOUNG, J.H. Statistical ecology: a population perspective. Kluwer Academic Publishers, v. 1, n.1, p.565, 1998. 